\title{
MALIGNANT CHANGE IN A SOLITARY CYLINDROMA: A RARE CASE REPORT
}

Shivaji D. Birare' ${ }^{1}$, Sunita S. Dantkale ${ }^{2}$, Snehal V. Chavhan ${ }^{3}$, Swapnil D. Chandekar ${ }^{4}$, Rahul R. Narkhede ${ }^{5}$

\section{HOW TO CITE THIS ARTICLE:}

Shivaji D. Birare, Sunita S. Dantkale, Snehal V. Chavhan, Swapnil D. Chandekar, Rahul R. Narkhede. "Malignant change in a Solitary Cylindroma: A Rare Case Report". Journal of Evolution of Medical and Dental Sciences 2014; Vol. 3, Issue 25, June 23; Page: 6909-6912, DOI: 10.14260/jemds/2014/2837

ABSTRACT: Cylindroma is a rare tumour which originates from skin appendages. Cylindromas are of two types namely solitary and multiple. Malignant transformation of cylindroma is unusual and is extremely rare in solitary type. They show strong predilection for middle aged and elderly females. We report a case of a 70 year old male patient presented with nodular swelling along with surface ulceration in the right axillary region since six months, which on histopathological examination revealed a case of malignant transformation of benign solitary cylindroma. We report a rare case of malignant cylindroma arising in a patient with solitary cylindroma at an unusual site.

KEYWORDS: Solitary cylindroma, Malignant cylindroma, malignant transformation of benign solitary cylindroma.

INTRODUCTION: Cylindromas are benign skin appendageal tumors most commonly occurring on head, neck and scalp. Cylindromas are most likely primitive sweat gland tumors differentiating toward either the eccrine or apocrine line. ${ }^{1}$ These tumors are of two distinct clinical types namely solitary and multiple. Solitary cylindroma occur sporadically and occur most commonly on the skin of the head and neck. Multiple cylindromas are inherited in an autosomal dominant pattern. It occurs on scalp, rarely on trunk and extremities. ${ }^{2,3}$

Multiple lesions can cover the entire scalp giving an appearance of a disfiguring turban-like appearance hence the eponym "turban tumor". ${ }^{3}$ Malignant transformation of a solitary cylindroma is extremely rare. Malignant transformation occurs more commonly in the multiple variant than the solitary cylindromas. ${ }^{4}$

CASE REPORT: A 70 year old male patient presented with painless nodular swelling with surface ulceration in the right axillary region since six months. There was no history of such type of lesion in the family. After surgical excision we received nodular tissue mass along with skin flap measuring $7.5 \times 4.5 \times 3 \mathrm{cms}$. Skin flap showed an ulcer measuring $2 \times 2 \mathrm{cms}$. Cut surface show greyish white appearance. Tissue was submitted for histopathological examination.

Microscopy showed islands of epithelial cells arranged in" jigsaw like" pattern separated by irregular hyaline sheath. Islands were composed of two types of cells. Cells at the periphery were small with scanty cytoplasm and hyperchromatic nuclei showing palisading arrangement while large cells with pale cytoplasm and oval vesicular nuclei were seen in the centre of the islands.

Droplets of hyaline are also seen in many islands. In other areas of tumor, the cells were arranged in sheets and lobules. Here the cells showed marked anaplasia and pleomorphism with loss of all three features like peripheral palisading, dual population and jigsaw pattern. Areas of necrosis were also noted. The hyaline material comprising the sheath was PAS positive. The microscopic findings were suggestive of malignant transformation of benign solitary cylindroma. 
DISCUSSION: Cylindroma is an uncommon skin appendage tumor that may occur either as solitary or multiple lesions. Ancell first described multiple cylindromas of the head and abdomen in 1842.1,5 Billroth and Beobachlung coined the term cylindroma in 1859 due to the epithelial elements of such growth being enclosed in well-defined 'cylinders' of connective tissue. ${ }^{6}$ The first description of malignant cylindrocarcinoma was made by Wiedemann in 1929.7

Multiple cylindromas can be associated with Brooke-Spiegler syndrome which also includes trichoepitheliomas and spiradenomas. Unique gene CY LD on chromosome 16 has been identified, which is considered to be responsible for multiple cylindromas. ${ }^{3,8}$ Malignant transformation of benign cylindroma is very rare. Extensive search of literature showed 72 documented cases of malignant cylindroma. ${ }^{4}$ Hosnuter et al revealed 36 malignant cylindroma and out of which only 9 were solitary. ${ }^{1,9}$ Malignant cylindroma occur in $5^{\text {th }}$ to $9^{\text {th }}$ decade of life, with a slight female predominance. ${ }^{4}$ Our patient is 70 year old male presenting with a solitary noduloulcerative growth in the right axillary region.

Cutaneous cylindroma presents with pink, skin colored, nodular growth; it may be solitary or multiple and vary in size from a few millimetres to centimetres. Malignant transformation commonly presents with ulceration, rapid growth, bleeding and blue to pink coloration of the nodules.1,4,8 The lesions are usually painless but it is not unusual to have pain. On microscopy it showed islands of cells showing marked nuclear anaplasia and pleomorphism with loss of hyaline sheath, jigsaw pattern and palisading at the periphery. ${ }^{3,10}$ Similar histological findings were seen in our case which also correlated with other studies. ${ }^{1,9}$

Malignant cylindroma being locally aggressive tumor can cause erosion of underlying structure and bone and can even metastasize to distant organ like stomach, thyroid, liver, lung and bones.1,3,9 Transcranial erosion and transcranial invasion by cylindromas has also been reported.3,11 In our case there was absence of lymphatic or vascular invasion.

Immunohistochemically epithelial cells express markers like CEA, EMA, CK6, CK19 and CK7 and myoepithelial cells express S-100 and alpha-smooth muscle actin.1,3,10 Immunohistochemistry is not helpful in distinguishing benign from malignant cylindroma.

The preferred mode of treatment for solitary lesions is wide local excision because of the recurrence risk. ${ }^{1,4}$ Jamshidi et al suggested that primary lesions should be excised with minimum 2 cms laterally and $1 \mathrm{~cm}$ basal surgical margins. ${ }^{12}$ Other treatments include scalping, Mohs' micrographic surgery, laser ablation, electrodessication/curettage cryotherapy, trichloroacetic acid, retinoic acid, carbon dioxide laser, and radiotherapy.3, 4 In order to avoid the recurrence of the tumor, radiotherapy is advised after complete resection. Also radiotherapy seems to be an option in inoperable tumors. ${ }^{4}$

CONCLUSION: Malignant transformation of benign solitary cylindroma is a rare occurrence. Malignant cylindroma being an aggressive tumor has a tendency for local destruction and distant metastasis. Therefore, early diagnosis and management offers a patient the best possibility for cure.

\section{REFERENCES:}

1. Bansal C, Batra M, Lal N, Srivastava AN. Solitary cylindroma with malignant transformation. Indian J Dermatol. 2012, Mar; 57(2):141-3. 
2. Gerretsen AL, van der Putte SC, Deenstra W, van Vloten WA. Cutaneous cylindroma with malignant transformation. Cancer. 1993 Sep 1; 72(5): 1618-23.

3. Kuklani RM, Glavin FL, Bhattacharyya I. Malignant cylindroma of the scalp arising in a setting of multiple cylindromatosis: a case report. Head Neck Pathol. 2009 Dec; 3(4): 315-9.

4. Akgul GG, Yenidogan E, Dinc S, Pak I, Colakoglu MK, Gulcelik MA. Malign cylindroma of the scalp with multiple cervical lymph node metastasis-A case report. Int J Surg Case Rep. 2013; 4(7): 589-92

5. Ancell H. History of a remarkable case of tumors, developed on the head and face, accompanied with similar disease on the abdomen. Med Chir Trans 1842; 25: 227.

6. Billroth T. Beobachlung U. Gertchwulste der Spelcheldrusen. Virchows. Arch Pathol Anat 1859; 17 (4):357-75.

7. Wiedemann A. Further contributions to the knowledge of the so-called cylindroma of the scalp. Arch Dermatol 1929; 159: 180-7.

8. Elder DE, Elenitsas R, Johnson BL, Murphy GF, Xu X.Histopathology of the skin. $10^{\text {th }}$ edition. USA: Lippincott Williams and Wilkins; 2009.

9. Hosnuter M, Babuccu O, Kargi E, Numanoglu, G, Koca R, Babucccu B. Malignant solitary cylindroma of the scalp.Eur J Plast Surg (2004); 27:246-248

10. Mckee PH, Colonje E, Granter SR. Pathology of the skin with clinical correlation. $3^{\text {rd }}$ edition. USA: Elsevier mosby; 2005.

11. Wyld L, Bullen S, Browning FS. Transcranial erosion of a benign dermal cylindroma. Ann Plast Surg 1996; 36: 194-6.

12. Jamshidi M, Nowak MA, Chiu YT, Perry EA, Fatteh SM. Giant malignant eccrine spiradenoma of the scalp. Dermatologic Surgery.1999; 25 (1): 45-48.

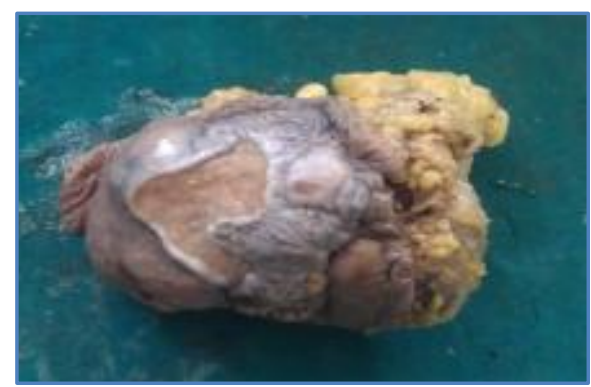

Fig. 1: Noduloulcerative mass

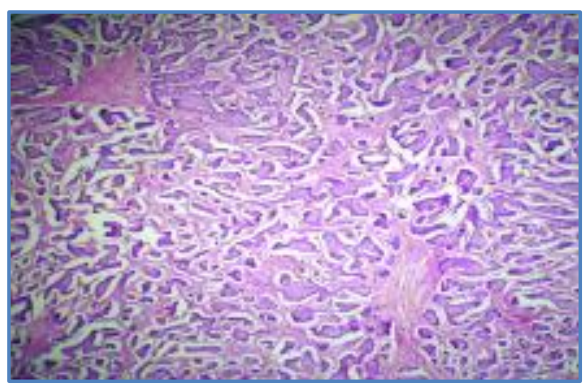

Fig. 2: Benign cylindroma-cells arranged in jigsaw pattern separated by hyaline sheath $(4 \mathrm{x}, \mathrm{H} \& \mathrm{E})$

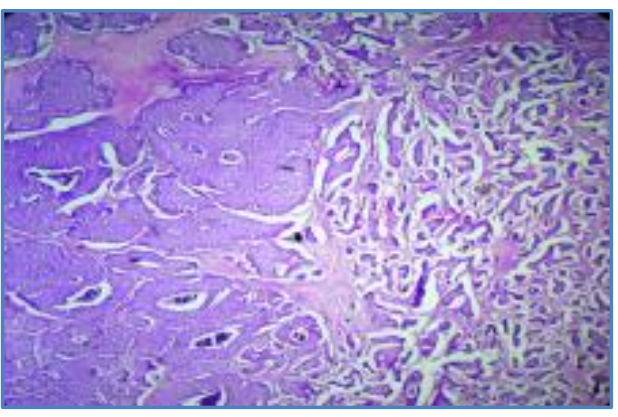

Fig. 3: Malignant transformation of benign cylindroma-tumor cells arranged in sheets and lobules (4x , H \& E) 


\section{CASE REPORT}

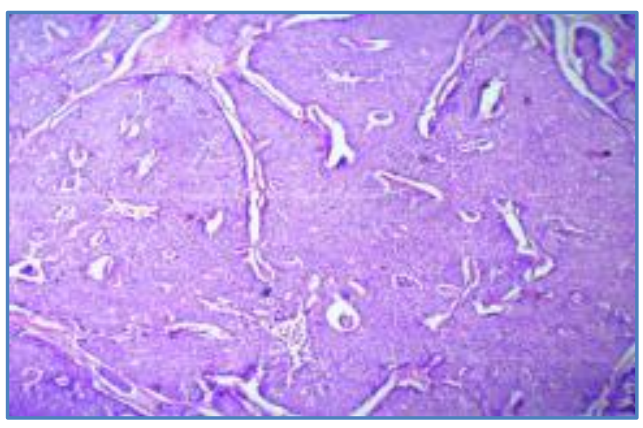

Fig. 4: Malignant cylindroma,loss

of dual cell population, hyaline sheath, and jigsaw pattern (10x, H \& E)

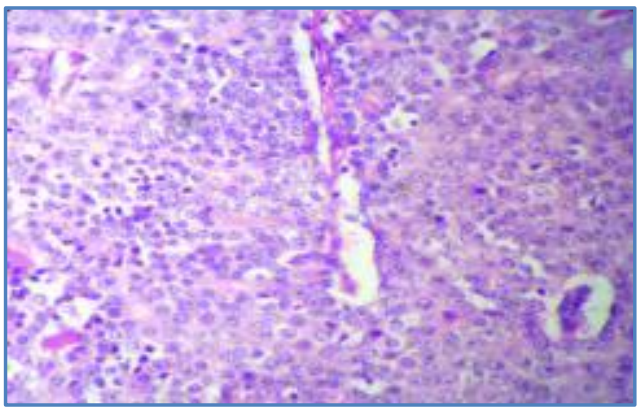

Fig. 5:Tumor cell showing large pleomorphic vesicular nuclei and prominent nucleoli. (40x, H \& E)

\section{AUTHORS:}

1. Shivaji D. Birare

2. Sunita S. Dantkale

3. Snehal V. Chavhan

4. Swapnil D. Chandekar

5. Rahul R. Narkhede

\section{PARTICULARS OF CONTRIBUTORS:}

1. Associate Professor, Department of Pathology, Government Medical College, Latur.

2. Associate Professor and HOD, Department of Pathology, Government Medical College, Latur.

3. Post Graduate Student, Department of Pathology, Government Medical College, Latur.

4. Post Graduate Student, Department of Pathology, Government Medical College, Latur.

5. Assistant Professor, Department of Pathology, Government Medical College, Latur.

\section{NAME ADDRESS EMAIL ID OF THE CORRESPONDING AUTHOR:}

Dr. Snehal V. Chavhan,

Department of Pathology,

$3^{\text {rd }}$ Floor, College Building,

Government Medical College,

Latur-413512.

Email: snehalvchavhan@gmail.com

Date of Submission: 01/05/2014.

Date of Peer Review: 02/05/2014.

Date of Acceptance: 13/06/2014.

Date of Publishing: 18/06/2014. 